\title{
Oil spill problems from the aspects of the Claim, Performance and Insurance Functions
}

\author{
Fariha Saeed \\ Department of Management, Faculty of Commerce, University of Chittagong, Bangladesh
}

\begin{abstract}
This article discusses oil spills from the aspects of the claim, performance and insurance functions of the results of tracing oil spills at sea depending on many factors, including the physical, chemical and toxicity characteristics of oil, as well as its distribution which is influenced by the dynamics of seawater: tides, wind, waves and currents. The impact of insoluble oil compounds in water will float and cause seawater to turn black. Several components of oil sink and accumulate in sediments as pollutant deposits in sand and rocks on the beach. Claim settlement in Marine Hull and Machinery is the same as general loss insurance. The rights of the insured that must be fulfilled by the insurer, if it has met the terms and conditions determined by the insurer and stated in the policy. Members receive protection \& indemnity for this guarantee so that members are protected and receive compensation from associations that are not covered or insufficiently covered by insurance.
\end{abstract}

Keywords: Oil Spills, Claim, Insurance.

Received: August 12, 2020

Received in Revised: August 24, 2020

Accepted: August 27, 2020

\section{Introduction}

Claims of cargo ships A transportation of goods by sea is usually based on a legal agreement in the form of an agreement, either in the form of a bills of lading (B / L) or a Charter Party $(\mathrm{C} / \mathrm{P})$ in that agreement, one party is usually the owner of the goods requiring sea transportation services (Tetley, 1983). Meanwhile, other parties are sellers or providers of sea transportation services (transporters/ship owners). In its implementation, sometimes one party breaks the promise, and one type of default is the lack of or damage to the cargo of the ship that was promised.

As befits a legal engagement, default by one party gives the other party the right to claim compensation for the losses incurred. In connection with this paper, the effort to demand such compensation is referred to as a "claim" or a direct adaptation of the word claim in English. In practice, efforts to get compensation for deficiencies or damage, even though it is obvious.

Planet Earth, has large reserves of oil and gas, which are trapped deep beneath its surface. Sometimes, these reserves are hacked so that some oil or gas seeps out (Leggett, 2005). This natural occurrence is also one of the causes of major damage to environmental ecosystems.

On the other hand, there are times when the same problem occurs due to human activities, especially oil spills which cause damage to marine ecosystems. These activities include shipping, fishing, and other marine biological resources, offshore oil and gas drilling, oil spill accidents from tankers, and leaks of offshore oil platforms (Anderson \& LaBelle, 2000). Various accidents at sea that caused massive oil spills, such as Showa Maru in the Strait of Malacca (1975), Exxon Valdez in Alasca (1989), Amoco Cadiz in the English Channel (1978), blow up in British Petroleum's Macondo oil well (BP) in the Gulf of Mexico (2010), and the leak of the Montara oil rig in the Timor Sea (2009). 
Not only when accidents occur, ship and tanker operations also make a major contribution to marine pollution, especially water ballasts (balancing water) in oil tankers, which always have to be removed during loading.

The impact of an oil spill at sea depends on many factors, including the physical, chemical, and toxicity characteristics of the oil, as well as its distribution which is influenced by seawater dynamics: tides, winds, waves, and currents. The impact of insoluble oil compounds in water will float and cause seawater to turn black. Several components of oil sink and accumulate in sediments as pollutant deposits in sand and rocks on the beach.

A more strategic effort is preventive action to anticipate the accident of the oil spill itself. Low awareness of environmental aspects both individually, in groups and institutions is a limitation of the implementation of early prevention efforts. This environmental awareness effort can be through public education, to imposing strict sanctions if there is a violation of environmental pollution.

Charter Party is a document agreed between the owner of the ship who agrees to charter the ship and the lessee who agrees to charter the ship. Charter can be in the form of the entire ship or the entire cargo space, it can also be part of the cargo space, in accordance with the terms and conditions agreed in the Charter Party (Anderson III, 2001).

Those whose boats are chartered need to read carefully and fully understand every clause contained in the agreement. In particular, on additional clauses to really understand them.

Party charter consists of three main types, namely bareboat charter parties (also called demise charters), Voyage Charter parties, and Time Charter parties (Djadjev, 2017).

\section{Bareboat Charter Party}

This type of party charter is basically based on time, however, the shipowner does not provide the captain or crew. The charterer is given temporary power, as if the ship belongs to him. The tenant is responsible for the appointment of the captain, crew, fuel costs, and so on.

However, there may be a clause that states the chief technician must be approved by the shipowner. The charterer is responsible for the safety of the ship. The ship is inspected in advance by both parties before departure and after. Charter parties need to establish that the ship remains in good condition after use.

\section{Voyage Charter Party}

Rental fees in voyage charter parties are based on specific trips. The owner of the ship agrees to be carried for one or a number of specific trips. Tenants deliver goods and pay rental fees. Usually, the cost calculation is calculated from the amount of cargo or calculated in bulk. If desired by the owner of the goods or the charterer, the shipowner or carrier needs to issue a bill of lading or bill of lading on each voyage.

\section{Time Charter Party}

In a time-based ship charter, there is charter according to time is an agreement with the name of the party that one (the charterer) binds himself for a certain time, provides a certain ship, to his party (the charterer) with the intention of using said ship is in voyage at sea for the purposes of the latter party, with the payment of a price, which is calculated according to the length of time. The transportation services provided by the charterer for the benefit of the charterer are carried out for a certain period of time and the ship. The boat trip is carried out by the captain and crew provided by the shipowner. Rental costs are determined according to a certain time proportionally. 


\section{Claim, Performance, Insurance Functions}

Plan and carry out activities that include:

\section{Claim}

a. Verification of supporting documents for claims (oil spills, damage to assets, damage to cargo), and clarification with users regarding these claims.

b. Claim calculation process (oil spills, damage to assets, damage to cargo).

c. Analysis, verification, clarification, and coordination of rebuttal claims (oil spills, damage to assets, damage to cargo).

d. Claim settlement process (oil spill, asset damage, cargo damage) with a third party (shipowner).'

\section{Performance}

a. Monitoring claims by collecting data and collecting documents related to claims to identify obstacles in the claim settlement process in the claim, performance, insurance, and user functions.

b. Recommend effective ways to resolve the obstacles that occur, so that the target of accelerating claim settlement can be achieved.

\section{Insurance}

a. As an insurance coordinator related to Pertamina's ship insurance.

b. Handling insurance claims issues for both $H \& M$ claims or P\&I insurance claims that occur against Pertamina's ships (not limited to incidents against 3rd parties).

c. Ensure that insurance policies and information related to other insurance updates are distributed properly to the function of the asset owner and other related functions.

d. Ensure that all Pertamina vessels are covered by insurance, coordinate with FRI's function as insurance coordinator at Pertamina regarding the premium policy and the period of coverage.

e. Working together with the function of the asset owner to ensure that Pertamina's ships meet the recommendations given by the insurance as the insurer of the assets, so that the potential for unclaimable events can be minimized.

\section{Definition of Marine Hull and Machinery Insurance}

Marine Hull and Machinery Insurance is a type of loss insurance which is an insurance agreement that covers the hulls and engines of marine vessels ( $\mathrm{Li}, 2014)$. In this case, the Insurer enters into a guarantee agreement with the insured regarding an object, namely a ship. The parties to the Marine Hull and Machinery insurance agreement are as follows: Insurer, Insured, Surveyor and Loss Adjuster.

\section{Marine Hull and Machinery Claim}

Claim settlement in Marine Hull and Machinery is the same as general loss insurance. The rights of the insured that must be fulfilled by the insurer, if it has met the terms and conditions determined by the insurer and stated in the policy. Payment of claims in Marine Hull and Machinery insurance is the same as in general insurance, including Pure claim payment, namely payment of a claim because the claim has met the specified requirements attached with complete supporting documents. Exgratia payment, namely the payment of claims or compensation provided by the insurer even though the insurer is not obliged to provide compensation. The size or form of this compensation is not regulated in the policy. In general, this exgratia is given solely because of commercial considerations such as large 
prime customers, influential customers, customers with a history of good (rare) claims for compensation. Payment of compromise claims, namely payment of claims based on the agreement of the parties concerned because

\section{P\&I (Protection \& Indemnity Insurance) Insurance}

Protection means "protecting" the owner of the ship, INDEMNITY means "insuring" club members for losses that are not covered by insurance. With the existence of Protection and Indemnity Insurance, this means reducing the losses suffered by ship owners (Kierr, 1968).

Protection \& Indemnity Insurance is an association of ship owners where this association will cover the losses suffered by ship owners, where these losses are not covered by insurance (Ronneberg, 1990). So members get protection \& indemnity for this guarantee so that members become protected and get compensation from associations which are not covered or not sufficiently covered by insurance. For this, protection and indemnity is no different from ordinary insurance, only here it is limited to ship owners.

\section{Conclusion}

A more strategic effort is preventive action to anticipate the oil spill accident itself. Low awareness of environmental aspects both individually, in groups and institutions is a limitation of the implementation of early prevention efforts. Claim settlement in Marine Hull and Machinery is the same as general loss insurance. The rights of the insured that must be fulfilled by the insurer, if it has met the terms and conditions determined by the insurer and stated in the policy.

\section{References}

Tetley, W. (1983). Waybills: the modern contract of carriage of goods by sea. J. Mar. L. \& Com., 14, 465.

Leggett, J. (2005). The empty tank: Oil, gas, hot air, and the coming global financial catastrophe. Random House.

Djadjev, I. (2017). Shipping and the Law on Bills of Lading and Charter Parties. In The Obligations of the Carrier Regarding the Cargo (pp. 1-30). Springer, Cham.

Li, L. (2014). Marine Insurance Law-General Conditions in Hull, Cargo and P\&I Covers. Asian Bus. Law., 13, 129.

Kierr, R. H. (1968). Effect of Direct Action Statutes on P and I Insurance, on Various Other Insurances of Maritime Liabilities, and on Limitation of Shipowners' Liability. Tul. L. Rev., 43, 638 .

Ronneberg Jr, N. J. (1990). An Introduction to the Protection \& (and) Indemnity Clubs and the Marine Insurance They Provide. USF Mar. LJ, 3, 1.

Anderson III, H. E. (2001). Subject to Details and Charter Party Negotiations. Tul. Mar. $L J, 26,61$.

Anderson, C. M., \& LaBelle, R. P. (2000). Update of comparative occurrence rates for offshore oil spills. Spill Science \& Technology Bulletin, 6(5-6), 303-321. 